Kinestetik : Jurnal Imiah Pendidikan Jasmani 5 (3) (2021)

Kinestetik : Jurnal Imiah Pendidikan Jasmani

https://ejournal.unib.ac.id/index.php/kinestetik/index

DOI : 10.33369/jk.v5i3.16732

\title{
EVALUATION OF ONLINE LEARNING IMPLEMENTATION IN THE MIDDLE OF THE COVID-19 CORONA VIRUS PANDEMIC IN PALANGKA RAYA SMA PENJAS SUBJECTS
}

Yosita wisman', Indrianto Arif Ramadhana $^{2}$, Jeff Agung Perdana ${ }^{3}$

${ }^{123}$ Physical Education, Health And Recreation Department, Faculty of Education and Teachers

Training, University of Palangkaraya, Indonesia

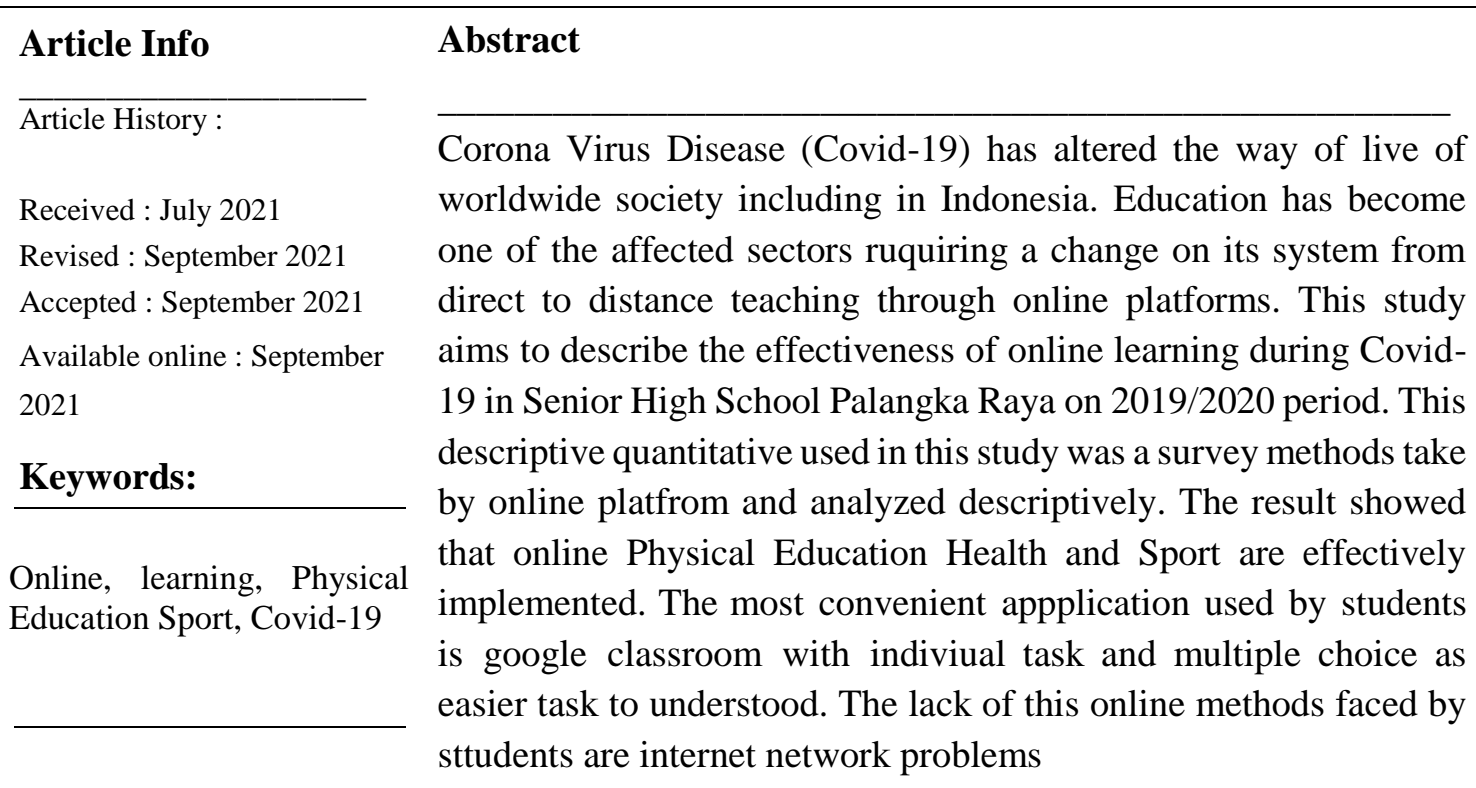

Corresponding address : Palangkaraya

ISSN 2685-6514 (online)

Corresponding email : yossitayosie@yahoo.com

ISSN 2477-331X (print) 


\section{INTRODUCTION}

The COVID-19 pandemic is a tragedy that grieves the entire population of the earth. Currently, the whole World is under threat of Coronavirus disease (COVID-19) (N \& Patil, 2020).

All segments of human life on earth are disrupted, without exception education. The Covid-19 pandemic in Indonesia has paralyzed teaching and learning activities in educational institutions. At least 1.3 billion schools in the world are closed due (https://www.merdeka.com/uang/kemendikbu d-catat-646200-sekolah-tutup-akibat-viruscorona.html). Many countries closed schools, colleges, and universities, including Indonesia. The crisis really came suddenly, especially in the world of education, the government in any part of the world including Indonesia had to take a bitter decision to close several places that made a lot of people. The school is the only object of monitoring that certainly gets special attention (Rasmitadila et al., 2020).

Education, especially the state, in facilitating the continuity of schools for all educational stakeholders to carry out distance learning (Syah, 2020) Government policies carried out by instructing courageous learning with the aim of minimizing direct contact and gathering mass are one of the alternatives carried out.

It is recommended that the state be stricter in implementing Stay-at-Home, suppress the spread by imposing a massive lockdown, improve health services, and increase the availability of personal protective equipment. (Setiati \& Azwar, 2020). The international health organization or World Health Organization (WHO) announced the status of the Covid-19 virus as a pandemic requiring the whole world to immediately make efforts to stop and overcome its effects. The 2019 coronavirus disease (COVID-19) outbreak is a Public Health Emergency of
International Concern (PHEIC), the World Health Organization (WHO) convenes an International Health Regulations Emergency Committee (EC) (Jee, 2020).

The way the government has chosen as an effort to suppress the spread of the virus in Indonesia is physical restrictions or physical distancing. Restrictions cause many changes in various aspects of social, economic, cultural, and even educational life. The Indonesian Ministry of Education issued a Circular Letter of the Minister of Education and Culture No. 4 of 2020 concerning the Implementation of Policies and Education in an Emergency Period for the Spread of Corona Virus Disease (Covid-19) by canceling and replacing the teaching (Kemdikbud, 2020).

Learning process $(\mathrm{KBM})$ at schools using an online system at home. Online learning, online, or distance learning aims to meet educational standards by utilizing information technology by using computer devices or gadgets that are interconnected with students and teachers as well as students and lecturers (Pakpahan \& Fitriani, 2020). To switch from a face-to-face learning model or meet in person, then turn into online (online) it really requires a lot of effort and costs (Arif, 2020).

Covid-19 could fundamentally change the way sport operates in the future and requires further analysis (Parnell et al., 2020). it is said that covid-19 could fundamentally change the way sports operate in the future and requires further analysis, could use online learning in sports education in particular.

learning sports online in order to have good cardiorespiratory freshness is expected to have a good body resistance too (Arif et al., 2021). Technology keeps students connected to teachers so that knowledge transfer can still be carried out properly. There are now a variety of digital technologies that can be used to augment and enhance work, learning and public health strategies (Komalasari, 2020). 
The technology that can be used to carry out this learning is a cell phone or cellphone. Students do online learning and interact with teachers using several applications that are used such as google classroom, zoom, google meet and whatsapp group (Yunitasari \& Hanifah, 2020). According to a temporary analysis survey, in general, the online learning media used at SMA Palangka Raya are Webex, Zoom, Google Classroom, Google Forms, Instagram, and Whatsapp, Google Meet, YouTube, and Facebook applications. Online technology is expected to be a solution as a learning medium during the Covid-19 pandemic (Hidayat \& Noeraida, 2020). Evaluation of the Implementation of Online Learning in the Midst of the Covid-19 Corona Virus Pandemic in the Physical Education Subject of the Palangka Raya High School. This research has a novelty that looks at how courageous learning is in the midst of a pandemic so that it will know what the effectiveness of learning is.

The purpose of this study was to determine how big the perceptions of teachers and students in physical learning were seen from the form of evaluation that had been carried out at Palangka Raya High School. Each application has advantages and disadvantages in its use. Therefore, the effectiveness of online PJOK learning needs to be known so as to find clear improvement steps to be ready to face the new normal era. This is what the author uses to describe the effectiveness of PJOK learning carried out at SMA Negeri Palangka Raya. So that the contribution in this research is very important for the advancement of education in Indonesia, especially education in Palangkaraya.

Therefore, the effectiveness of online PJOK learning needs to be known so that it is evaluated to find clear corrective steps to be ready to face the new normal era.

\section{METHODS}

This research is a descriptive quantitative study to describe the effectiveness of online learning in the subjects of Physical Education, Sports and Health (PJOK). According to (Sugiyono, 2017).

The research uses a qualitative strategy, namely research that emphasizes objective phenomena and is studied qualitatively. This study does not manipulate data or make changes to the variables involved in the study, but describes the conditions for implementing physical education learning during the COVID-19 pandemic. This research is also a survey research because there are components that describe qualitatively the opinion tendencies of a certain population by examining a sample of the population, namely physical education teachers and high school students of Palangka Raya. The research method is qualitative, carried out by collecting data using a research questionnaire. The design used uses an ethnographic approach. Variables are examined in the process of implementing physical education learning at SMA Palangkaraya. Based on the analysis of random sampling, 1 (one) SMA was the target of the study. The subjects studied were teachers and students of SMA Palangka Raya. The tool used is a questionnaire which is distributed online. The population in this study were physical education teachers and high school students of Palangka Raya. The research sample was Physical Education teachers at each Palangka Raya High School and Palangka Raya High School students who were randomly selected. Determination of the number of samples in this study using Roscoe guidelines in (Sugiono, 2016). that the appropriate sample size in a study is 30 to 500 .

The sampling technique was simple random sampling. The data collection technique used an online questionnaire, which 
contained closed and open questions analysis and the statistical model used.

Data were analyzed using descriptive statistics with the help of computers. The questionnaire uses google forms. Validity and reliability tests were carried out on groups of physical education teachers and high school students of Palangka Raya. The analysis was carried out qualitatively regarding the perceptions of physical education teachers and high school students in the implementation of the physical education learning process. Qualitative analysis was carried out through content-analysis based on the information collected in the questionnaire.

The stages of the research are arranged based on systematic steps so that the workflow is clear and indicators can be achieved. The research steps include preparation, field observation and processing. Preparation includes preparing research designs, selecting research locations, administering permits and field assessments, preparing research instruments and conducting validity and reliability tests. Field activities consist of understanding the research background, collecting data using instruments. Data collection in this study was conducted to determine the perception of each point of view of both students and physical education teachers in the process of implementing physical education learning. Data collection using an online questionnaire method. Prior to data collection, the researcher delivered instructions for filling out the online questionnaire.

\section{RESULTS}

Characteristics of Respondents

Respondents in this study were students of SMP Negeri 4 Pakem Grades 7 and 8. The total number of respondents was 237 people with details of 124 grade 7 students and 113 grade 8 students.

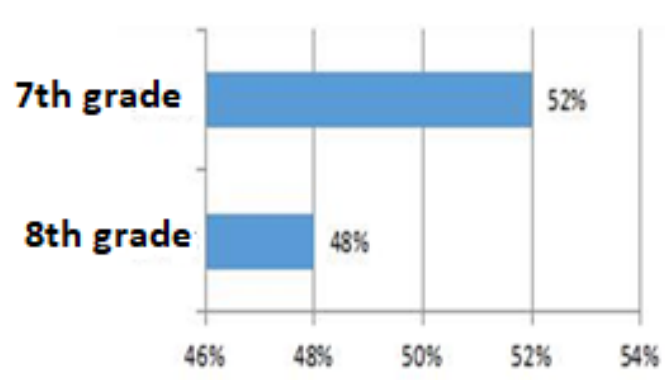

Figure 1. Distribution of Respondents Filling Out the Questionnaire

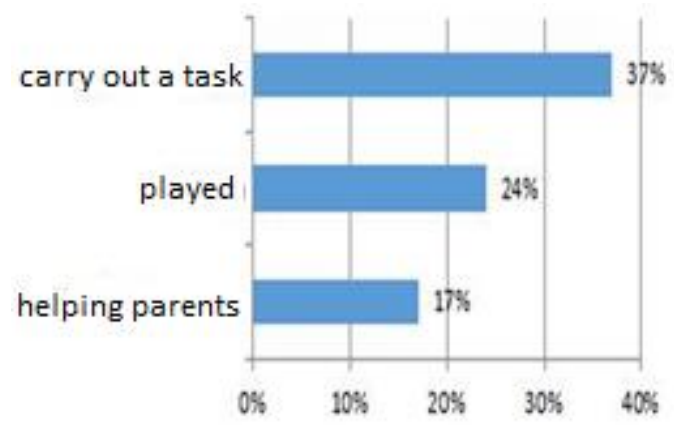

Figure 2. Student Activities during Online Learning

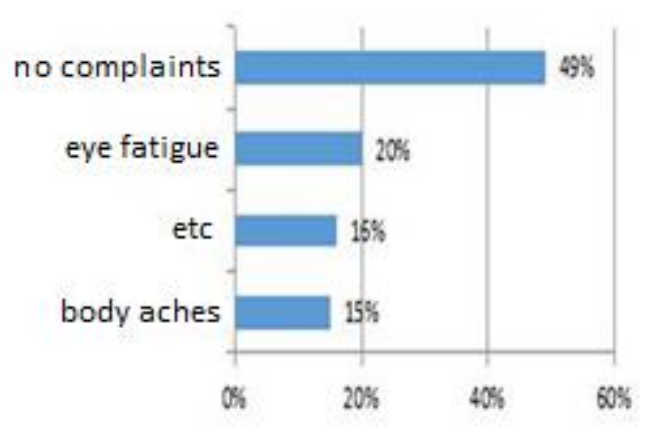

Figure 3. Physical Complaints during Online Learning 


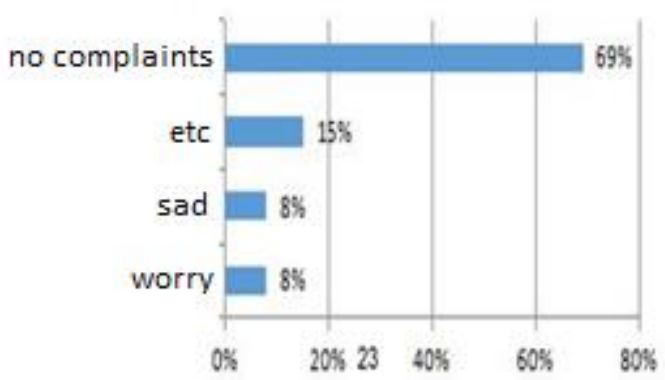

Figure 4. Psychological Complaints during Online Learning

Based on Figure 1, it can be seen that the respondents who filled out the most questionnaires were grade 7 students with a percentage of $52 \%$ and grade 8 students with a percentage of $48 \%$. During online learning, the most activities carried out by students were doing assignments as much as $37 \%$, playing as much as $24 \%$, and helping parents as much as 17\%. Most of the students at SMP Negeri 4 Pakem do not experience many physical and psychological complaints, but there are still disturbances such as eye fatigue, worry, and sadness.

\section{Online Learning Conditions}

The condition of online learning in PJOK's eyes is seen from several aspects, namely students' understanding of online learning materials, applications that are easily accessible to students, assignments, obstacles during learning, the benefits of physical learning, and the effectiveness of online learning.

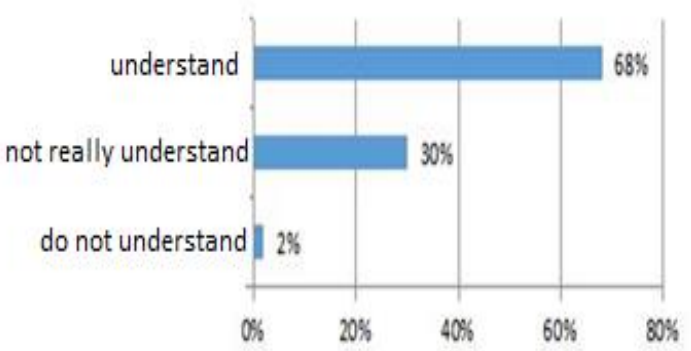

Figure 5. Students' Understanding of Materials during Online Learning

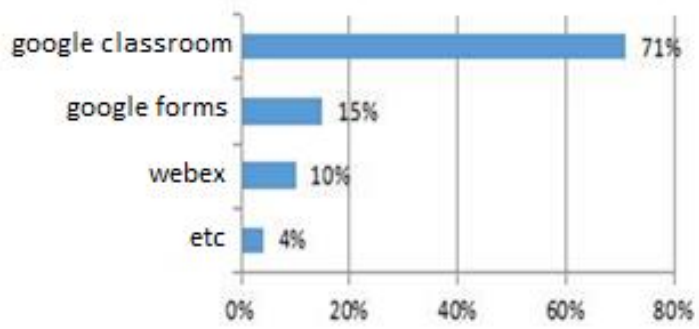

Figure 6. Easy-to-Use Applications for Online Learning

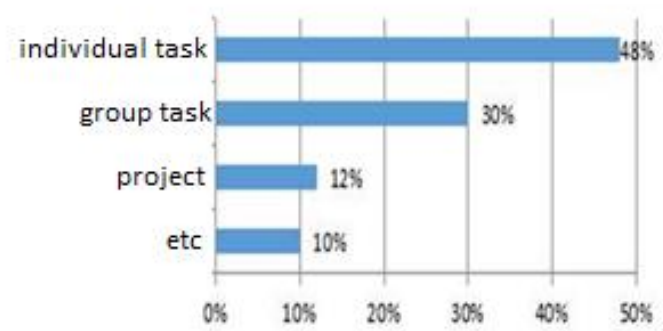

Figure 7. Easy Assignments to Do during Online Learning

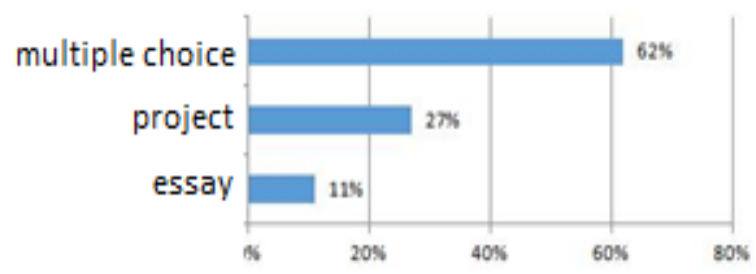

Figure 8. Types of Tasks Most Liked by Students during Online Learning

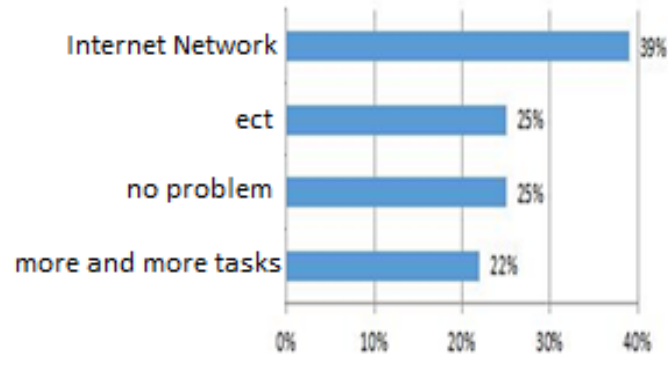

Figure 9. Obstacles Faced during Online Learning 


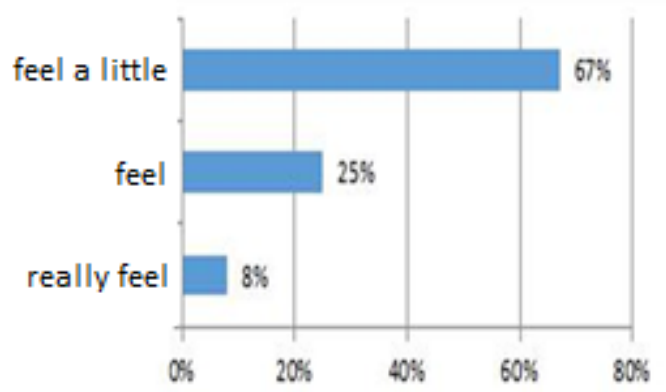

Figure 10. Physical Benefits after Online Learning

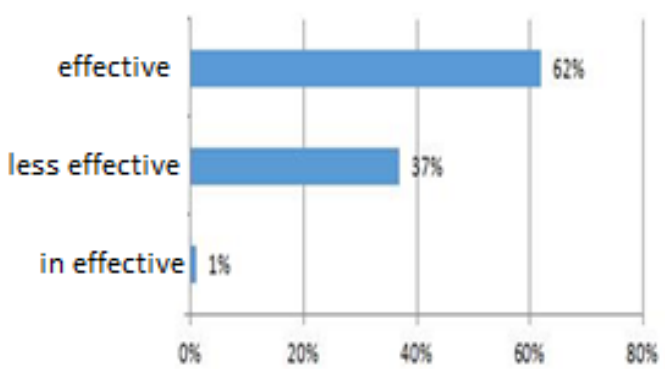

Figure 11. Effectiveness of PJOK Online Learning

Based on the picture above, it can be seen that the respondents' answers varied in each question. Figure 3 explains that PJOK online learning materials can be understood by $68 \%$ of students and $30 \%$ of students feel they do not understand and $1 \%$ of students do not understand online learning at all. In Figure 5 it can be seen that $71 \%$ of students use Google Classroom because it is considered an easy-touse application. In addition, Google Forms $15 \%$ and Webex $10 \%$ while other applications used by students during online learning are Whatsapp and Instagram.

Figure 6 shows that the assignments that are easiest for students to do are individual assignments as much as $48 \%$, then group assignments as much as $30 \%$ and projects $12 \%$. Meanwhile, other assignments chosen by students were video conferences, reading books, and discussions as much as $10 \%$. In Figure 8 it can be explained that the assignments that students like the most are multiple choice assignments as much as $62 \%$, projects as much as $27 \%$ and essays as much as $11 \%$.

Constraints faced by students during online learning can be seen in Figure 9. As many as $39 \%$ of students feel that internet network disturbances and wasteful quotas hinder the online learning process the most. Meanwhile, as many as $22 \%$ felt that the increasing number of tasks from various subjects made the focus on doing the task disturbed. Others as much as $22 \%$ were found to be lazy, falling asleep, being late for learning and electrical disturbances.

Figure 10 explains that as many as $67 \%$ of students only slightly benefited from online learning that involved skills assessment. As many as $25 \%$ of students felt the benefits physically while $8 \%$ did not feel any benefit from the practice of skills in PJOK learning that was carried out online. Although physically students do not feel useful, in Figure 11 it can be seen that as many as $62 \%$ of students assess PJOK learning to be effective. Meanwhile, $37 \%$ of students considered learning less effective and $1 \%$ of students assessed that learning was not effective.

PJOK learning at SMP Negeri 4 Pakem was considered effective in terms of understanding the material, completeness of mobile devices, minimal obstacles faced and student assessments. However, there are several things that can be used as evaluation material for teachers and students. During PJOK learning, students feel little physical benefit in learning. This is directly proportional to the number of students who spend a lot of time playing gadgets or social media. According to (Pane, 2015).

Simple sports that can be used as choices in maintaining health are brisk walking, gymnastics, swimming, running, and cycling and are carried out at least 3 times a week. Teachers can deal with this deficiency by providing a routine program with clear task 
details and students also reporting the results of their health improvement activities through sports.

Learning to face the new normal is done by innovating learning methods so that students are active and feel the physical benefits of learning. Giving multiple choice assignments can be modified with essays or project assignments so that students can still think critically and feel challenged to work solve learning problems created by educators. Educators are also required to pay attention to health protocols in the implementation of learning and not to force themselves because students' health must be prioritized.

\section{Discussion}

Based on this research, it is known that the respondents who filled out the most questionnaires were grade 7 students with a percentage of $52 \%$ and grade 8 students with a percentage of $48 \%$. During online learning, the most activities carried out by students were doing assignments as much as $37 \%$, playing as much as $24 \%$, and helping parents as much as $17 \%$.

Then as many as $67 \%$ of students feel little benefit from online learning that involves skills assessment. As many as $25 \%$ of students feel the benefits physically while $8 \%$ do not feel any benefit from the practice of skills in PJOK learning that is carried out online. Although physically students do not feel useful, in Figure 11 it can be seen that as many as $62 \%$ of students assess PJOK learning to be effective. Meanwhile, $37 \%$ of students considered learning less effective and $1 \%$ of students assessed that learning was not effective.

During the COVID-19 pandemic, physical education teachers in particular, are required to be more creative in presenting material. Especially when teachers have to carry out online teaching and learning implementation programs which of course have not been thought of before. In addition, physical education teachers should also be aware of the importance of performance for students and for schools because with good performance they can not only help students achieve optimal learning outcomes but will also be able to help smooth learning activities carried out by schools in general. All levels of the Palangka Raya Education Office can facilitate the obstacles of physical education learning, especially during the COVID-19 pandemic so that the learning process can continue and does not reduce the essentials of its implementation. Follow-up to conduct similar research to improve the competence of physical education teachers in Palangka Raya.

\section{CONCLUSION}

The Covid-19 pandemic has changed the education system in Indonesia into distance learning using online media. This is done in order to reduce and stop the chain of distribution. The use of information technology in distance learning during the Covid-19 pandemic at SMP Negeri 4 Pakem was considered effective by students in terms of understanding the material, mastering the application, and understanding the material.

However, there are still learning weaknesses, namely internet network constraints, the physical usefulness of physical learning is lacking, and the type of task is monotonous. Educators have a very decisive role in the success of this online learning. Educators must create creative, innovative, and recreational learning methods that stimulate students to be willing to be actively involved in online learning and feel the meaning of learning.

\section{REFERENCES}

Arif, Y. (2020). Pelatihan Pengembangan Pembelajaran Olahraga Renang Melalui Model Pembelajaran E-Learning Dan Face-To-Face ( Blended Learning ) Dalam Mata Kuliah. 4(2), 246-252. 
http://www.jurnal-

umbuton.ac.id/index.php/ppm/article/vie w/630/648

Arif, Y., Boleng, L. M., Louk, M. J. H., \& Fufu, R. D. A. (2021). Identification Of Fresh Cardiorespiration Of 2018 Nusa Cendana University Of Penjaskesrek Students During Covid-19. Kinestetik: Jurnal Ilmiah Pendidikan Jasmani. https://doi.org/10.33369/jk.v5i1.12796

Hidayat, D., \& Noeraida. (2020). Pengalaman Komunikasi Siswa Melakukan Kelas Online Selama Pandemi Covid - 19. JIKE Jurnal Ilmu Komunikasi Efek.

Jee, Y. (2020). WHO International Health Regulations Emergency Committee for the COVID-19 outbreak. In Epidemiology and Health. https://doi.org/10.4178/epih.e2020013

Kemdikbud. (2020). Surat Ederan Nomor 1 Tahun 2020 Tentang Pencegahan Penyebaran COVID-19 Di Perguruan Tinggi, Kementrian Pendidikan Dan Kebudayaan. Http://Kemdikbud.Go.Id/.

Komalasari, R. (2020). MANFAAT TEKNOLOGI INFORMASI DAN KOMUNIKASI DI MASA PANDEMI COVID $19 . \quad$ TEMATIK. https://doi.org/10.38204/tematik.v7i1.36 9

N, V. R., \& Patil, S. B. (2020). Indian Publications on SARS-CoV-2: A bibliometric study of WHO COVID-19 database. Diabetes and Metabolic Syndrome: Clinical Research and Reviews. https://doi.org/10.1016/j.dsx.2020.07.00 7

Pakpahan, R., \& Fitriani, Y. (2020). Analisa Pemafaatan Teknologi Informasi Dalam Pemeblajaran Jarak Jauh Di Tengah Pandemi Virus Corona Covid-19. JISAMAR (Journal of Information System, Applied, Management, Accounting and Researh).

Pane, B. S. (2015). Peranan Olahraga Dalam Meningkatkan Kesehatan. Jurnal Pengabdian Kepada Masyarakat.

Parnell, D., Widdop, P., Bond, A., \& Wilson, R. (2020). COVID-19, networks and sport. In Managing Sport and Leisure. https://doi.org/10.1080/23750472.2020.1 750100
Rasmitadila, Aliyyah, R. R., Rachmadtullah, R., Samsudin, A., Syaodih, E., Nurtanto, M., \& Tambunan, A. R. S. (2020). The perceptions of primary school teachers of online learning during the covid-19 pandemic period: A case study in Indonesia. Journal of Ethnic and Cultural Studies. https://doi.org/10.29333/ejecs/388

Setiati, S., \& Azwar, M. K. (2020). COVID-19 and Indonesia. Acta Medica Indonesiana.

Sugiono. (2016). Metode Penelitan Kuantitatif, kualitatif dan R\&D. Bandung: Alfabeta.

Sugiyono. (2017). Sugiyono, Metode Penelitian. Penelitian.

Syah, R. H. (2020). Dampak Covid-19 pada Pendidikan di Indonesia: Sekolah, Keterampilan, dan Proses Pembelajaran. SALAM: Jurnal Sosial Dan Budaya SyarI. https://doi.org/10.15408/sjsbs.v7i5.1531 4

Yunitasari, R., \& Hanifah, U. (2020). Pengaruh Pembelajaran Daring terhadap Minat Belajar Siswa pada Masa COVID 19. EDUKATIF : JURNAL ILMU PENDIDIKAN. https://doi.org/10.31004/edukatif.v2i3.14 2 